\title{
Vegetation diversity and structure of urban parks in Cilegon City, Indonesia, and local residents' perception of its function
}

\author{
MUHLISIN $^{1, \bullet}$, JOHAN ISKANDAR ${ }^{1,2,5}$, BUDHI GUNAWAN ${ }^{1,3,5}$, MARTHA FANI CAHYANDITO ${ }^{1,4}$ \\ ${ }^{1}$ Doctoral Program in Environmental Science, Graduate School, Universitas Padjadjaran. Jl. Dipati Ukur No. 35, Bandung 40132, West Java, Indonesia \\ "email: muhlisinsidik@gmail.com \\ ${ }^{2}$ Department of Biology, Faculty of Mathematics and Natural Sciences, Universitas Padjadjaran. Jl. Raya Bandung-Sumedang Km 21, Jatinangor, \\ Sumedang 45363, West Java, Indonesia \\ ${ }^{3}$ Department of Anthropology, Faculty of Social and Political Science, Universitas Padjadjaran. Jl. Raya Bandung-Sumedang Km 21, Jatinangor, \\ Sumedang 45363, West Java, Indonesia \\ ${ }^{4}$ Department of Management and Business, Faculty of Economics and Business, Universitas Padjadjaran. J1. Dipati Ukur No. 35, Bandung 40132, West \\ Java, Indonesia \\ ${ }^{5}$ Center for Environment and Sustainability Science, Universitas Padjadjaran. Jl. Sekeloa Selatan I, Bandung 40132, West Java, Indonesia
}

Manuscript received: 29 November 2020. Revision accepted: 8 June 2021

\begin{abstract}
Muhlisin, Iskandar J, Gunawan B, Cahyandito MF. 2021. Vegetation diversity and structure of urban parks in Cilegon City, Indonesia, and local residents' perception of its function. Biodiversitas 22: 2589-2603. The existence of urban parks is very essential for cities because they provide ecosystem services and benefits to humans. Diversity and structure of vegetation in urban parks play significant role in delivering several functions of ecosystem services. This paper aims to explore and analyze the vegetation diversity and structure, as well as ecosystem services of eight urban parks in Cilegon City, Banten Province, Indonesia. Vegetation analysis and residents' perception are also conducted in this research. The analysis of vegetation is focused on horizontal structure of vegetation, including plant diversity, plant habitus, the original distribution of the plants, and vertical structure of vegetation (canopy stratification and vegetation profile). The residents' perceptions are collected using interviews of selected respondents. The identification of vegetation recorded 114 plant species from 46 families are found in the concerned urban parks, however, the diversity and species richness in these parks tended to be low. The vegetation communities are uncertain and dominated primarily by non-native and invasive species. The canopy stratification is relatively homogeneous with the dominant plants having less than one meter in height, such as Ruellia simplex and Syzygium paniculatum. The vegetation planted in the urban parks are mostly ornamental plants that provide much more aesthetic function rather than ecological purpose, daily human needs, or other ecosystem services. This fact shows that urban parks in the study area have only few ecosystem services, hence they need some improvements in order to have more environmental services and to be able to enjoy more by the community.
\end{abstract}

Keywords: Ecosystem services, medicinal plant, plant diversity, urban park, vegetation structure

\section{INTRODUCTION}

Urban park planted with various species provides a wide range of ecosystem benefits including regulating, supporting, cultural, and provisioning services (Iskandar and Iskandar 2016b; Pulighe et al. 2016). In term of regulating service, urban park can mitigate climate change by storing carbon (Zölch et al. 2016), improve air quality by acting as city lungs that absorb carbon dioxide $\left(\mathrm{CO}_{2}\right)$ and produce oxygen (Manes et al. 2012; Janhall 2015; Zhang et al. 2017; Jones 2018; Rózová et al. 2020), and reducing environmental temperatures (Bagheri et al. 2017). Urban park also increases water quality and reduce rainwater runoff (Zhang et al. 2015a) so that it can help to control urban flooding (Yao et al. 2015; Leimer et al. 2014).

In terms of supporting services, urban parks can increase soil fertility and soil organic carbon storage (Chen et al. 2018; Lange et al. 2015; Eisenhauer et al. 2018) and serves as habitat for wild animals, particularly birds and insects (Iskandar and Iskandar 2016). The urban park vegetation also provides provision services as genetic resources that produce edible fruits, herbal medicines, timber, and others (Nagendra and Gopal 2010; Palliwoda et al. 2017; Lacy and Shackleton 2017).

In addition to providing regulatory, supporting, and provision services, urban park also delivers cultural services, for instance, it provides a playground for children, physical activities, recreation, educational purposes (e.g., a place for discussion, a learning resource, and conservation education), and other social interactions (Miller 1988; Zhou 2012; Shan 2014; Amos and Maloy 2015; Wolsink 2016; Klein 2018). It also increases the aesthetic value of the urban landscape (Lacy and Shackleton 2017). Meanwhile, urban park can also help curb citizen health problem including allergies, asthma, cardiovascular disease, and reduce acute health effects (Zhang et al. 2015b; Ulmer et al. 2016; Kabisch et al. 2017; Reid et al. 2017; Markevych et al. 2017; Cole et al. 2019). Viewed from provisioning services, urban parks can facilitate economic activities such as becoming a tourist and culinary destination (Akmar et al 2018; Leeuwen et al. 2010; Schipperijn 2010).

The knowledge about urban parks is important in its management and provides an understanding for the community to participate in plant conservation (Dearborn 
and Kark 2010; Lepczyk et al. 2017; Smith et al. 2018). Some studies regarding urban parks were undertaken by some scholars in several themes, including microclimate assessment in the chosen localities of Nitra, Slovakia (Rózová et al. 2020), assessment of toxic effect on plant, risk of environmental and health on the urban park soils (Brtnický et al. 2019), the influence of urban park on the temperature of local urban environment (Yan et al. 2018), composition and structure of vegetation of urban parks in different countries (Zhao et al. 2010; Pearse et al. 2018; Talal and Santelmann 2019), the relationship between vegetation and ecological functions, such as microclimate and carbon sinks (Cundaningsih et al. 2015; Erdianto et al. 2019), and perception and knowledge of plant diversity related to urban park management (Muratet et al. 2015; Talal and Santelmann 2020). In more details, some studies looked at the particular uses of the plants cultivated in urban park including for traditional medicine (Taek et al. 2019; Rahmawati et al. 2020), ornamental plants (Lacy and Shackleton 2017), edible fruits (Lacy and Shackleton 2017), religious ceremonies (Dash et al. 2019; Sujarwo et al. 2020; Sutrisno et al. 2020), timber and fuelwood (Nagendra and Gopal 2010), and others.

While various studies on urban parks have been carried and knowledge regarding it is improved, some problems remain. For example, urban parks often have low quality in infrastructure and vegetation, poorly maintained, inadequate area, and converted function into urban infrastructure building (Yan et al. 2016). Urban park is sometimes dominated by infrastructure facilities rather than the vegetation, implying that the area for and diversity of the vegetation are inadequately low. Yet, there have not been many specific studies regarding horizontal and vertical vegetation structure, and vegetation function according to community opinion. This paper elucidates the vegetation structure and function of urban parks based on a case study conducted in eight urban parks in Cilegon City, Banten Province, Indonesia. The study on horizontal structure of vegetation includes plant diversity, plant habitus and the original distribution of the plant, while vertical structure of vegetation focuses on stratification of canopy and vegetation profile. The research also identifies the main function of vegetation in urban parks and vegetation benefit for human based on local resident's perception.

\section{MATERIALS AND METHODS}

\section{Study area and period}

The study was conducted in eight urban parks in Cilegon City, Province of Banten, Indonesia between January 2019 and June 2020. Five urban parks are categorized as main urban parks of which four parks are located in the government office area $\left(6^{\circ} 00^{\prime} 34^{\prime \prime} \mathrm{S} ; 106^{\circ}\right.$ 02' 37" E) namely Town Square Park, Children Park, Simpang Park, and Al-Hadid Park, while one park is 1500 $\mathrm{m}$ from the government office area namely Nurul Ikhlas Park which is located in front of the Great Mosque of Cilegon ( $\left.6^{\circ} 01^{\prime} 05.32^{\prime \prime} \mathrm{S} ; 106^{\circ} 03^{\prime} 13.67^{\prime \prime} \mathrm{E}\right)$. The other three parks are categorized as sub-district parks with their locations are scattered in each sub-district, namely Cilegon Sub-district Park (6 $6^{\circ} 01,59.96^{\circ} \mathrm{S} ; 106^{\circ} 02^{\prime} 59.03 ”$ E), Jombang Sub-district Park (6 $6^{\circ} 00^{\prime} 49.44^{\prime \prime}$ S; $106^{\circ} 02^{\prime}$ 59,03” E), and Purwakarta Sub-district Park ( $5^{\circ} 59^{\prime} 28.73^{\prime \prime}$ S; $106^{\circ} 03^{\prime} 31.18^{\prime \prime}$ ) (Figure 1).

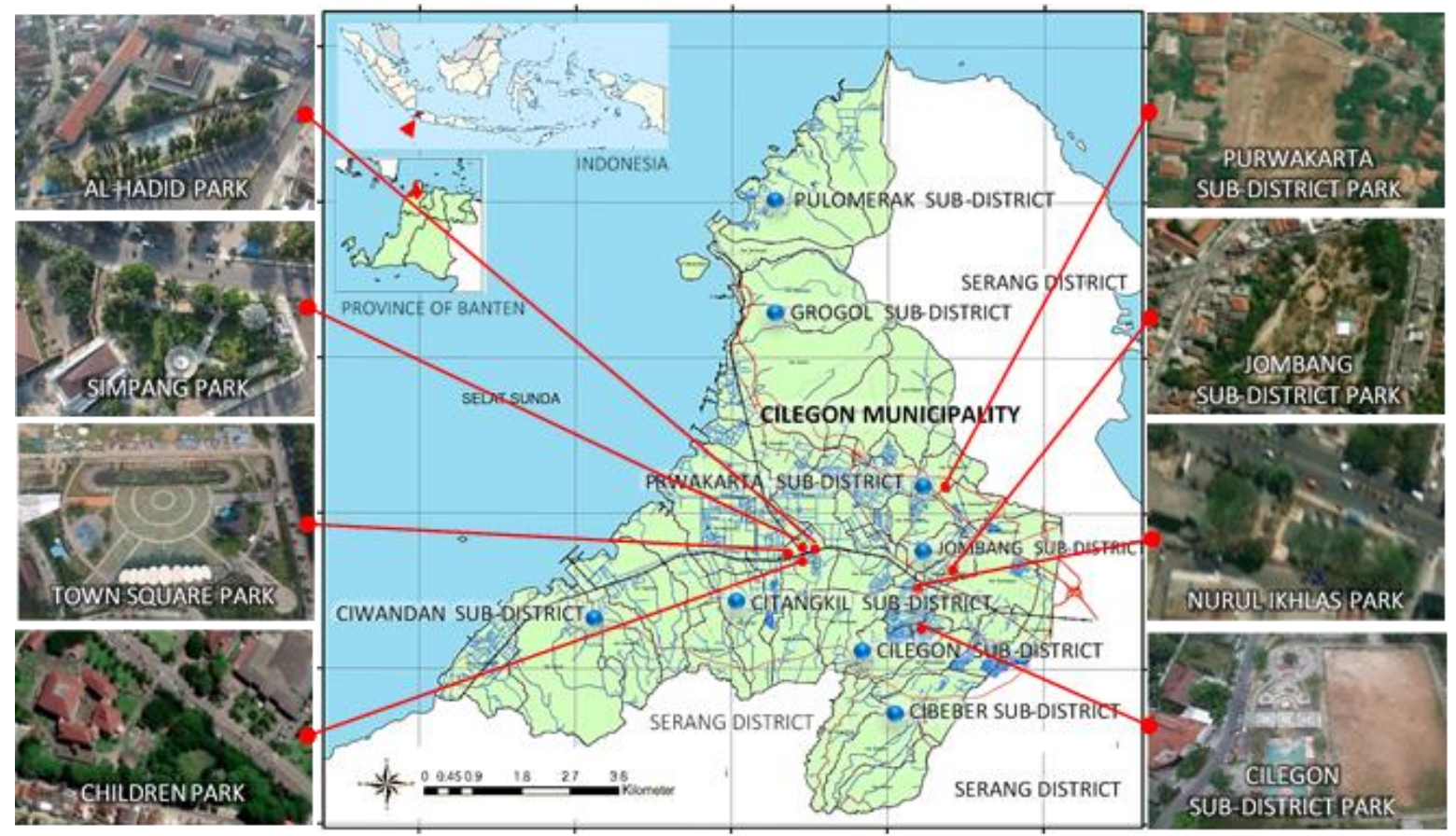

Figure 1. The study location of eight urban parks located in Cilegon City, Province of Banten, Indonesia. (Source: Bappeda Cilegon 2010; Bing Maps-Satelite, 2019) 
The structure of urban parks in Cilegon City usually consists of vegetation cover and open space. The vegetation cover is normally dominated by various cultivated plants, while the open space consists of pedestrian, gazebo, sport fields, park bench, playing ground, and additional facilities such as plaza and food court as found in Town-square Park. Meanwhile, the open space of the sub-district urban parks in Cilegon City usually consists of football field, basketball field, playing ground, pedestrian, and temporary children's playground such as a night market, except in Purwakarta Sub-district Park which is still in the process of development. Based on the vegetation coverage of the eight urban parks in Cilegon City, it revealed that three urban parks have predominant green cover, namely Nurul Ikhlas Park (89\%), Jombang Sub-district Park (78\%), and Simpang Park (64\%), while the others have less than $50 \%$ vegetation cover.

Cilegon Town-square Park is the largest urban park with an area of 4.97 ha, while the other city parks such as Children Park, Al-Hadid Park, Simpang Park, dan Nurul Ikhlas Park are less than 1 ha with $0.89,0.29,0.27$, and 0.27 ha, respectively. Meanwhile, the largest sub-district urban park is Jombang Sub-district Park (2.2 ha), while the other parks namely Cilegon Sub-district Park and Purwakarta Sub-district Park have an area of 0.93 and 0.27 ha, respectively.

\section{Data collection procedures}

The study used a combination of quantitative and qualitative research methods. A modified vegetation analysis (Mueller-Dombois and Ellenberg 1974; Soerianegara and Indrawan 1978) was applied to record species of plants in eight urban parks in Cilegon City. We assumed that each urban park is considered as a plot and each plot in an urban park is regarded as a subplot (Suin 2002). The species name and individual number of all species in every plot were recorded and identified using several references (Partomihardjo et al. 2014; Thomas 2011; Karyati and Adhi 2018; ITIS 2020) and classification of plant habitus was done following Sukarya et al. (2013). The vegetation structure of the urban park was arranged horizontally and vertically. The horizontal distribution consisted of species composition and plant diversity based on habitus and the original distribution of the plant. Meanwhile, the vertical structure is a canopy stratification that forms urban park vegetation. Canopy stratification can be divided into five strata, namely $<1 \mathrm{~m}, 1-2 \mathrm{~m}, 2-5 \mathrm{~m}$, $5-10 \mathrm{~m}$, and > $10 \mathrm{~m}$ (Iskandar and Iskandar 2016). Then vegetation profile diagram is made to get an overview of the layers of the canopy that make up the urban park (Leslie and Wilson 2009).

Qualitative data collection techniques through semistructured interviews and in-depth interviews were used to explore residents' perceptions on the existence of urban parks and knowledge about the function of plants in the urban park in Cilegon City. Fifty respondents were selected using purposive sampling method consisting of urban park cleaners, traders around the urban park, government employees, private employees/entrepreneurs, teachers and lecturers, housewives, and elderly people. The question began with the respondent's perception on the quality and benefit of urban park, and the function/use of the plant that occurred in the urban park. The plant function in question included the primary use of the plant in the urban park, for example for shade, directed, and ornamental (Lestari et al. 2010; Sukewijaya and Kohdrata 2015), and its use in general purposes such as edible fruits, medicinal, timber, and vegetable/seasoning.

\section{Data analysis}

The structure and function of urban park vegetation were analyzed using some indexes, including Summed Dominance Ratio (SDR), indices of diversity, species richness, evenness, and similarity. The qualitative data of resident's perception of urban parks and resident's opinions on the function of urban park vegetation were analyzed by cross-checking it with data collected through observations.

\section{Vegetation structure}

Summed Dominance Ratio (SDR) index was used to analyze the plant species dominance and frequency of the eight urban parks in Cilegon City. SDR was calculated using the formula below (Iskandar and Iskandar 2016):

$$
S D R=\frac{F R+D R}{2}
$$

Where: SDR is Summed Dominance Ratio, FR is Relative Frequency and DR is Relative Dominance. Relative Frequency (FR) was calculated by dividing the frequency of species-i by the sum frequency of all species then multiplying by 100 percent. Meanwhile, the Frequency (F) was obtained from dividing the number of urban parks in which a particular species occurs with the total urban park samples. Dominance Relative (DR) was calculated by dividing the individual number of species-i by the dominance of all species multiplied by 100 percent. Dominance of species-i (Di) was obtained by dividing the individual number of species-i by the individual number of all species.

The species diversity index was calculated using the Shannon-Wiener formula (Spellerberg and Fedor 2003; Agrawal and Gopal 2013):

$$
H^{\prime}=-\sum_{i=1}^{s} p i \cdot \ln p i
$$

Where: $H^{\prime}$ is the index of species diversity, $s$ is the species numbers, and $p i$ is the proportion between individuals and species (Carey and Delaney 2010). H'>3 indicates high species diversity, while $\mathrm{H}^{\prime}<1$ and $1<\mathrm{H}^{\prime}<3$ indicates low and moderate diversity, respectively (Iskandar and Iskandar 2016).

The canopy stratification diversity index was also calculated using the Shannon-Wiener formula, where $p i$ is the proportion of total cover of vegetation on the soil from the canopy layer in understorey and upper layer. This measure is important since urban parks which have the high canopy stratification diversity index show high diversity of birds and insects (Iskandar 2017). 
Another common method of biodiversity measurement density index is the Margalef's Species Richness Index formula (Gamito 2010):

$$
d=\frac{S-1}{\ln N}
$$

Where: $S$ is the species number and $N$ is the total individual number in a sample. If $d<3.5$ then the category of species richness is low; $3.5<\mathrm{d}<5$ medium; and $\mathrm{d}>5$ high.

Evenness index value $(E)$ was used to investigate the stability of a community by assessing the distribution of individuals of a species within a community in a study unit (Iskandar and Iskandar 2016). The higher the $E$ value, the higher the species diversity in a community, and vice versa (Soerianegara and Indrawan 1976; Odum 1993). The index of evenness was calculated using the following formula.

$$
E=\frac{H^{\prime}}{H_{\text {max }}^{\prime}}
$$

Where: $E$ : Index of Evenness, $H^{\prime}$ : Index of Diversity, Hmax: $\ln S$ and $\mathrm{S}$ : Number of species found. The index of evenness value ranges from $0-1$ in which $0<E \leq 0.5$ indicates a depressed community, $0.5<E \leq 0.75$ is an unstable community, and $0.75<E \leq 1$ is a stable community.

The species similarity index shows the ratio of a species in different habitats. The species similarity index used formula prescribed by Sorensen (Odum and Baret 1972 ) and was calculated as follows.

$$
I S=\frac{2 C}{A+B}
$$

Where: IS the Sorensen Similarity Index; A: Plant species number in sample A; B: number of plant species present in sample B; $\mathrm{C}$ : number of species present in sample A and B in pairs. Similarity index of $100 \%$ means that two communities compared have exactly similar species, otherwise, similarity index of $0 \%$ means that the plant species of the two communities compared are totally different (Iskandar and Iskandar 2016).

\section{The use of plant perceived by residents}

Quantitative data analysis of structured interviews (questionnaires) was conducted using simple statistics with percentages and descriptive analysis. Meanwhile, qualitative data collected by field observation, and semistructured interviews were analyzed by cross-checking to get valid data, summarizing, synthesizing, and making narration with descriptive and evaluative analysis (Iskandar and Iskandar 2018).

\section{RESULTS AND DISCUSSION}

\section{Vegetation structure}

\section{Horizontal vegetation structure}

In total, across eight urban parks in Cilegon City observed in this study, there were 59,942 individuals of plant recorded, consisting of 114 species belong to 46 families (Table 1). The Town Square Park had the highest number of individual plants, amounting to 24,584 individuals. The urban park with the lowest number of individuals was Al-Hadid Park with 923 individuals. Meanwhile, the highest number of plant species and families were found in Jombang Sub-district Park with 58 species and 30 families. Purwakarta Sub-district Park is the park with the lowest number of species and families with seven species and four families. A survey in 2016 by the Environmental Agency in the entire city of Cilegon with an area of $17500 \mathrm{Ha}$, recorded as many as 216 plant species. This means that the number of plant species in the urban park is only $55 \%$ of the total plant species in Cilegon City.

Figure 2 shows that Fabaceae was the family dominated the urban parks in Cilegon City with 30 species (e.g. Pterocarpus indicus, Samanea saman, etc.), followed by Asparagaceae (e.g. Cordyline australis, Yucca aloifolia, etc.); Arecaceae (e.g. Roystonea regia, Veitchia merillii, etc.) and Apocynaceae (e.g. Catharanthus roseus, Allamanda cathartica, etc). This result is not surprising since, among the plant kingdom, Fabaceae is a plant family with the third-largest number of species after Asteraceae and Orchidaceae with 770 genera and 19,500 species (Beech et al. 2017; Azani et al. 2017; Gomes et al. 2018).

Table 2 presents the indices of species richness, diversity, evenness, and similarity. Based on the table, it is shown that the highest species richness index (d Margalef index) was found in Jombang Sub-district Park with 6.69, putting it in the high category. Meanwhile, those categorized as medium were found in Town Square Park and Simpang Park. Parks with low-category species richness were Children Park, Al-Hadid Park, and Nurul Ikhlas Park. Meanwhile, the lowest richness index was found in Purwakarta Sub-district Park with 0.72. Although Jombang Sub-district Park has less area extent than Town Square Park, it had higher species richness. Understanding the composition of the plant community in urban parks can help residents better manage green infrastructure, which is important for improving environmental health, and settlements in urban areas (Talal and Santelmann 2019).

Table 1. Vegetation composition in eight urban parks in Cilegon City, Banten, Indonesia

\begin{tabular}{lrcc}
\hline Urban park & $\begin{array}{c}\text { Number of } \\
\text { individual }\end{array}$ & $\begin{array}{c}\text { Number of } \\
\text { species }\end{array}$ & $\begin{array}{c}\text { Number of } \\
\text { family }\end{array}$ \\
\hline Town Square & 24,584 & 47 & 29 \\
Children & 4,612 & 24 & 15 \\
Simpang & 18,078 & 48 & 24 \\
Al-Hadid & 923 & 17 & 16 \\
Nurul Ikhlas & 1,390 & 15 & 12 \\
Cilegon SD & 978 & 13 & 8 \\
Jombang SD & 5,046 & 58 & 30 \\
Purwakarta SD & 4,331 & 7 & 4 \\
Total & 59,942 & 114 & 46 \\
\hline
\end{tabular}




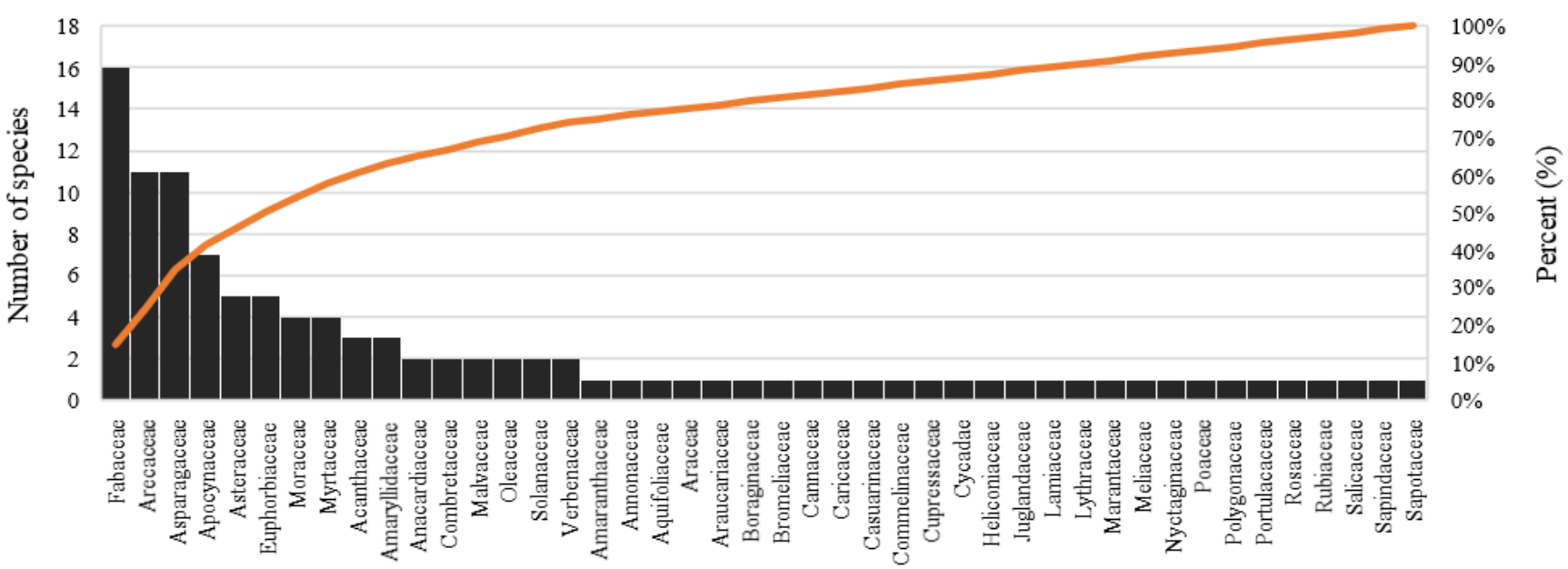

Plant Family

Figure 2. Vegetation composition based on the number of species in each family at eight urban parks in Cilegon City, Banten, Indonesia

Table 2. The indices of species richness, diversity, evenness and Sorensen similarity at eight urban parks in Cilegon City, Banten, Indonesia

\begin{tabular}{|c|c|c|c|c|c|c|c|c|c|c|c|c|c|}
\hline \multirow{2}{*}{ Urban park } & \multirow{2}{*}{ d } & \multirow{2}{*}{$\mathbf{H}^{\prime}$} & \multirow{2}{*}{$\mathbf{E}$} & \multicolumn{10}{|c|}{ Sorensen Similarity Index (IS) } \\
\hline & & & & Urban Park & & 1 & 2 & 3 & 4 & 5 & 6 & 7 & 8 \\
\hline Town Square & 4.55 & 1.61 & 0.42 & Town Square & 1 & & 46 & 38 & 29 & 43 & 31 & 40 & 8 \\
\hline Children & 2.73 & 1.60 & 0.50 & Children & 2 & & & 38 & 25 & 26 & 20 & 42 & 4 \\
\hline Simpang & 4.79 & 1.94 & 0.50 & Simpang & 3 & & & & 41 & 54 & 40 & 30 & 0 \\
\hline Al-Hadid & 2.34 & 1.90 & 0.67 & Al-Hadid & 4 & & & & & 44 & 33 & 19 & 0 \\
\hline Nurul Ikhlas & 1.93 & 1.81 & 0.67 & Nurul Ikhlas & 5 & & & & & & 43 & 19 & 0 \\
\hline Cilegon SD & 1.74 & 1.53 & 0.60 & Cilegon SD & 6 & & & & & & & 31 & 0 \\
\hline Jombang SD & 6.69 & 1.88 & 0.46 & Jombang SD & 7 & & & & & & & & 30 \\
\hline Purwakarta SD & 0.72 & 0.44 & 0.23 & Purwakarta SD & 8 & & & & & & & & \\
\hline
\end{tabular}

Note: d: Margalef Species Richness Index; H': Shannon-Wiener Diversity Index; E: Evenness Index; Numbers 1 to 8 in the table row represent urban park serial numbers as well as the urban park serial numbers in the table column

Plant species diversity index (H' Shannon-Wiener index) in urban park of Cilegon City is ranged from 1.53 to 1.94 point in the medium category, except in Purwakarta Sub-district Park which was in the low category (0.44). The high diversity of plant species in urban parks provides an important value in biodiversity conservation (Goddard et al. 2010) and puts urban parks as an important habitat of biodiversity (Lepczyk et al. 2017). According to vegetation development theory (Whitmore 1984), the older the plant community is, the more species it has, but the lower the number of individuals per species. In contrast, a young community will have a low number of species, but has a high number of individuals in each type. Jombang Sub-district Park had the highest number of species, indicating that the urban park is the oldest compared to other urban parks. This is in line with the fact that Jombang Sub-district Park was indeed built earlier than the other parks (Muhlisin 2016).

In general, the evenness index of the eight urban parks in Cilegon City is ranged from 0.23 to 0.67 , putting them into the unstable and depressed community category. In more detail, urban parks categorized as depressed communities were Town Square Park, Simpang Park, Children Park, Jombang Sub-district Park, and Purwakarta Sub-district Park. Meanwhile, the other urban parks were categorized as unstable communities, i.e., Al-Hadid Park, Nurul Ikhlas Park, and Cilegon Sub-district Park.
Based on Table 2, the parks that had an index of similarity of more than 50\% were Simpang Park and Nurul Ikhlas Park, while other parks had a similarity index of less than 50\%. Simpang Park and Nurul Ikhlas Park has similarity index of $54 \%$, meaning that $54 \%$ of the plant species in Simpang Park also occurred in Nurul Ikhlas Park. Purwakarta Sub-district Park had very low similarity with other urban parks (i.e., Town Square and Children Park with $8 \%$ and $4 \%$, respectively), even with some parks it had totally different species with index of zero. This is understandable since Purwakarta Sub-district Park has a low number of plant species because the park is still under development.

Based on habitus, the eight urban parks in Cilegon City generally dominated by trees, followed by shrubs and herbs while palm, succulent, and cycad had a lower proportion (Figure 3). Only Children Park had completely the five habitus, namely tree, shrub, herb, palm, succulent, and cycad. Jombang and Cilegon Subdistrict Parks had the highest percentage of trees among other areas, but the highest percentage of shrubs was found in Children Park, Simpang Park and Purwakarta Sub-district Park. Meanwhile, for herbs, the highest percentage was found in Al-Hadid Park and Nurul Ikhlas Park. However, in Town Square Park the percentage between trees, shrubs, and herbs was not very different. 


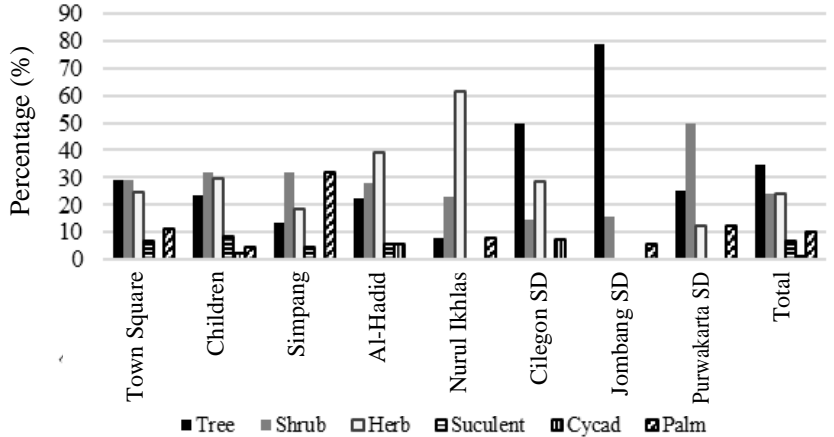

Figure 3. Vegetation composition based on plant habitus at eight urban parks in Cilegon City, Banten, Indonesia

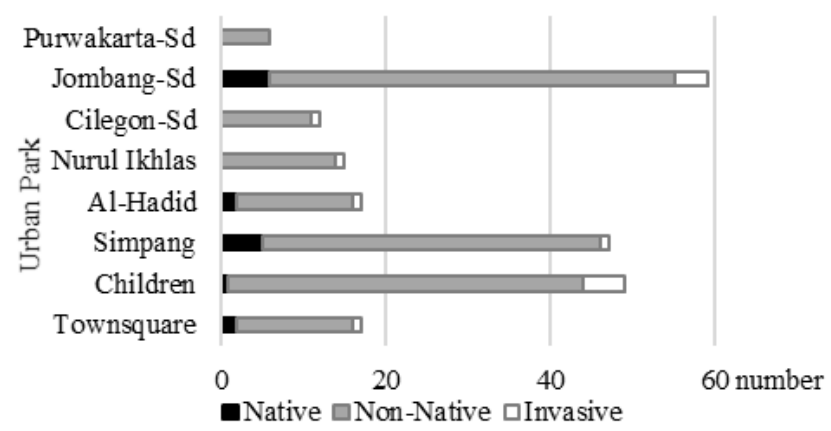

Figure 4. Vegetation composition based on the original distribution of the plant (i.e., native, non-native, and invasive plant) in eight urban parks in Cilegon City, Banten, Indonesia

Figure 4 showed that there were five urban parks that had native plant species, namely Town Square Park, Children Park, Simpang Park, Al-Hadid Park, and Jombang Sub-district Park. Meanwhile, Cilegon Sub-district Park and Nurul Ikhlas Park did not have native species with all were non-native and invasive species, and Purwakarta Subdistrict Park had all non-native species. In general, the number of native species was lower than that of non-native and invasive species. The proportion of non-native and invasive species were $91 \%$ and $6 \%$, respectively, while it was only $3 \%$ of native species. Similar finding was also reported by Nielsen et al. (2014) that about $50 \%$ of the plant species found in city parks were exotic. The same case was found by Li et al. (2006) showing that urban parks were unable to protect native biodiversity. The number of native plant species managed in urban parks and urban forests is low, while non-native increased rapidly. Urbanization causes the loss of the main wild land in the periphery and such wild land is replaced by managed land which is planted with plants that are suitable for the sake of beauty, food sources and other functions regardless of the origin of the plants (Hidayat and Kurnita 2018).

Native plant species play an important role in species richness. Burghardt et al. (2009) found that native plant species significantly increased the diversity of birds and butterflies compared to non-native plants managed conventionally. Likewise, exotic plants are not widely used by native pollinating insects (Goddard et al. 2010). In addition, alien invasive plant species spreading from the park have caused a major negative impact on economic and conservation problems worldwide. Taylor et al. (2016) also found that the abundance of individual species and species composition are more influenced by the existence of introduced plant species than by native plant species. Thus, the native species existence in urban parks is very important for biodiversity conservation.

Table 3 shows the Summed Dominance Ratio (SDR) of eight urban parks in Cilegon City. Mexican petunia (Ruellia simplex) had the highest SDR in Town Square Park and Simpang Parks, the plants with the highest SDR in Children, Al-Hadid and Cilegon Sub-district Parks were brush cherry (Syzygium paniculatum), golden dewdrop (Duranta erecta), and dogfennel (Eupatorium capillifolium), with SDR values of 28.83, 19.38, and 24.76, respectively. Meanwhile, Brazilian joyweed (Alternanthera brasiliana) was the plant with the highest SDR in Nurul Ikhlas and Jombang Sub-district Parks with SDR values of 20.71, and 30.17 respectively. The high SDR in each urban area means that the vegetation is scattered in the plots of each park with a high number of individuals (Iskandar and Iskandar 2016).

In general, the plants with the highest SDR in urban parks in Cilegon City were $R$. simplex with an SDR of 35.58 , followed by $A$. brasiliana and $S$. paniculatum with SDR values of 26.48 and 18.05 , respectively. It means that the $R$. simplex, A. brasiliana, and $S$. paniculatum were scattered throughout the urban parks in Cilegon City with a high number of individuals.

In detail, there were five plant species that had the highest SDR in each urban park, namely: $R$. simplex, $S$. paniculatum, D. erecta, E. capillifolium, and A. brasiliana. These plants were dominant in the urban parks in Cilegon City because they were intentionally planted to beautify the urban park. These plants are favorite shrubs and herbs as ornamental plants that have beautiful flowers or leaves.

Ruellia simplex is ornamental plant native to Mexico, Argentina, Brazil, western Bolivia, Paraguay, and Uruguay (Ezcurra and Daniel 2007). This plant has proven to have a competitive advantage as an invasive plant and can survive in floodplains with high rainfall. It dominates the cover over the ground, creating monotype invasions, because it can adapt to a variety of disturbed conditions (Karyati and Adhi 2018). This plant is very suitable as an ornamental plant or bordering plant because it has an attractive flower color (Smith et al. 2014).

Syzygium paniculatum is a shrub endemic to the coast of New South Wales (NSW), Australia with endangered status. The characteristic feature of this plant is that it has red leaflets, which then spread throughout the world as an ornamental plant to fill urban parks (NSW Office of Environment and Heritage 2012). Magenta Pilly Lily usually grows among other tree species which are generally native plants, but do not harm native species, but compete for light (Ramírez and Kallarackal 2019). 
Table 3. Ten plant species with the highest Summed Dominance Ratio (SDR) in eight urban parks in Cilegon City, Banten, Indonesia

\begin{tabular}{|c|c|c|c|c|c|c|c|c|c|c|c|}
\hline \multirow{2}{*}{ Species name } & \multirow{2}{*}{ Local name } & \multirow{2}{*}{ Habitus } & \multicolumn{9}{|c|}{ SDR of plant in urban park } \\
\hline & & & 1 & 2 & 3 & 4 & 5 & 6 & 7 & 8 & 9 \\
\hline Alstonia scholaris (L.) R.Br. & Pulai & Tree & & & & & & & 4.15 & 2.0 & \\
\hline Alternanthera brasiliana (L.) Kuntze & Bayam dempo & Herb & 16.59 & 18.51 & 18.25 & 17.32 & 20.71 & 18.37 & 30.17 & & 26.48 \\
\hline Bauhinia blakeana Dunn & Bunga kupu & Tree & & & & & & 4.23 & & & \\
\hline Bougainvillea glabra Choisy & Bunga kertas & Shrub & & & & & 3.07 & & & & 2.21 \\
\hline Canna indica $L$. & Bunga tasbih & Herb & 2.30 & & & & 12.44 & 5.51 & & & 2.94 \\
\hline Cordyline australis Endl. & Pandan bali & Shrub & & & 2.39 & & 2.97 & & & & 2.22 \\
\hline Cosmos sulphureus Cav. & Kenikir sulfur & Herb & & & & & 15.32 & & & & \\
\hline Cycas revoluta Thunb. & Pakis Haji & Cycad & & & & 6.26 & & & & & \\
\hline Delonix regia (Bojer) Raf. & Flamboyan & Tree & & & & & & 5.16 & & & \\
\hline Dracaena reflexa Lam. & Drakaena & Shrub & & & & & & & & 3.0 & \\
\hline Duranta erecta $\mathrm{L}$. & Anak Nakal & Shrub & 4.43 & 7.17 & 3.59 & 19.38 & 8.31 & 7.65 & & & 9.16 \\
\hline Erythrina crista-galli $\mathrm{L}$. & Dadap merah & Tree & & & & & & & 2.52 & & \\
\hline Erythrina variegata $\mathrm{L}$. & Dadap laut & Tree & & & & & & & 2.42 & & \\
\hline Eupatorium capillifolium (Lam.) Small & Adas Hutan & Herb & 4.95 & 8.24 & 9.99 & 4.40 & 4.62 & 24.76 & 3.68 & & 9.16 \\
\hline Excoecaria cochinchinensis L. & Sambang darah & Shrub & & 3.68 & & & & & & & \\
\hline Ficus benjamina $\mathrm{L}$. & Beringin & Tree & & & & & & 2.11 & 2.47 & & \\
\hline Eucalyptus deglupta Blume & Pohon pelangi & Tree & 2.20 & & & & & & & & \\
\hline Hakonechloa macra (Munro) Honda & Rumput Hakone & Herb & & & & 5.37 & & & & & \\
\hline Helicania rostrata Ruiz \& Pav. & Helikonia & Herb & & 0.45 & & & & & & & \\
\hline Hymenocallis littoralis Salisb & Bakungan & Herb & & & & & 4.58 & & & & \\
\hline Lantana urticoides Hayek. & Cente & Shrub & & & & 3.80 & & & & & \\
\hline Liriope spicata Lour. & Liriope & Herb & & & & & & & & 11.3 & \\
\hline Manihot uttilisima Pohl & Singkong & Shrub & & & & & & & & 3.9 & \\
\hline Melaleuca leucadendra Linn. & Kayu putih & Tree & & & & & & & 2.21 & & \\
\hline Polyalthia longifolia (Sonn.) Thwaites & Glodokan & Tree & & & & 8.97 & & & & & \\
\hline Portulaca pilosa $\mathrm{L}$. & Krokot & Suculent & & 1.49 & & & & & & & \\
\hline Pterocarpus indicus Willd. & Angsana & Tree & & & & & & & & 15.7 & \\
\hline Terminalia mantaly H. Perrier & Ketapang kencana & Tree & 1.98 & & & & & & 5.43 & 13.7 & \\
\hline Rhoeo discolor (L'Hér.) Hance ex Walp. & Adam Hawa & Herb & & 1.63 & & & & & & & 2.56 \\
\hline Roystonea regia O.F.Cook & Palem Raja & Palm & & & 4.23 & & & & & & \\
\hline Ruellia simplex C.Wright & Kencana Ungu & Herb & 30.21 & 25.83 & 26.63 & 16.84 & 16.07 & 22.41 & 9.60 & & 35.58 \\
\hline Samanea saman (Jacq.) Merr. & Trembesi & Tree & 1.73 & & & 2.94 & & 2.06 & 6.09 & & \\
\hline Sphagneticola calendulacea (L.) Pruski & Widelia & Herb & & 2.24 & & & & & & & \\
\hline Syzygium paniculatum Gaertn. & Pucuk merah & Shrub & 13.89 & 28.83 & 8.20 & & & & & & 18.05 \\
\hline Tectona grandis L.f. & Jati & Tree & & & & 2.94 & & & & & \\
\hline Veitchia merillii (Becc.) H.E.Moore & Palem Putri & Palm & & & 2.99 & & & & & & \\
\hline Vernonia elliptica DC. & Lee Kwan Yew & Shrub & & & & & & & & 50.4 & 6.89 \\
\hline Yucca aloifolia $\mathrm{L}$. & Yuka & Shrub & & & 3.25 & & & & & & \\
\hline Zinnia elegans Jacq. & Kembang kertas & Herb & 5.03 & & & & 3.04 & & & & \\
\hline
\end{tabular}

Note: 1. Cilegon Town Square Park; 2. Children Park; 3. Simpang Park; 4. Al-Hadid Park; 5. Nurul Ikhlas Park; 6. Cilegon Sub-district Park; 7 Jombang Sub-district Park; 8. Purwakarta Sub-district Park; 9. All of urban parks in Cilegon City.

Alternanthera brasiliana is native to sub-tropical and tropical regions in South America and Australia, often used as garden borders because of its attractive purple leaves and can be styled as a living fence. This species has the ability to phytoremediation pollution in soil polluted by machine waste. (Ogedegbe et al. 2013). Many of the encounters of A. brasiliana in many urban parks are more on the grounds of the use of these plants as ornamental plants that act as a barrier to the filler of the garden.

Duranta erecta is originated from America (CABI 2020). It can be formed as a fence as desired and has a moderate air pollution tolerance index (Okunlola et al. 2016). The genus Duranta is important in absorbing air pollutants and can be used to monitor vehicle exhaust emissions along the side of a busy highway (Raina and Bala 2011). The use of $D$. erecta in urban parks is more on the utilization as ornamental plants as a fence or garden barrier.
Eupatorium capillifolium (Dogfennel) is a herbaceous perennial plant in the family of Asteraceae. It is native to North America and is found mainly in the southeastern United States (Tabanca et al. 2010). Dogfennel currently ranks first as prairie weed that occurs most frequently in Florida. This plant grows well in open or abandoned land. The clearing of natural land due to human activities can provide new habitats so that this plant can potentially grow like a weed, because it is listed as one of the invasive alien species in Nepal (Irsyam and Hariri 2016; Sellers et al. 2019).

\section{Vertical vegetation structure}

Vertical vegetation structure can be studied from canopy stratification, profile diagrams, and the diversity of canopy stratification. Figure 5 shows the canopy stratification for the five height classifications. In terms of 
the number of individuals, most plants $(97.9 \%)$ in the urban parks of Cilegon City were found at a height of less than 1 $\mathrm{m}$, generally in the form of shrubs and herbs, while the other height categories were less than $1 \%$. In term of the number of species, plants with a height $<1 \mathrm{~m}$ was $38.51 \%$ had the highest percentage, while the number of species with the lowest percentage is at the height of 5-10 m.

In more detail, the canopy stratification of each urban park is shown in Table 4. In terms of the number of individuals, plants with a height of less than $1 \mathrm{~m}$ dominated each urban park with a range of $91.56 \%-99.44 \%$. The smallest and largest percentages were found in the Cilegon Sub-district Park and Simpang Park, respectively. Meanwhile, the other height categories were less than $1 \%$ except in Al-Hadid Park and Cilegon Sub-district Park, where the number of individuals greater than $10 \mathrm{~m}$ high reached $4.95 \%$ and $1.72 \%$, respectively. This shows that in general, urban parks in Cilegon City still lack the number of individual plants with a height of more than $1 \mathrm{~m}$, so that they appear less dense with trees. This is due to the choice of plants for urban parks favoring plants that function as ornamental plants in the form of shrubs and herbs rather than trees.

In terms of the number of species, plant species with a height of $<1 \mathrm{~m}$ had the highest percentage, ranging from 29.41 to $94.47 \%$. The smallest and largest percentages were found in Jombang Sub-district Park and Al-Hadid Park, respectively. In general, the number of plant species with height of 5-10 m and greater than $10 \mathrm{~m}$ in each urban park was less than 10\%, except in Children Park, Cilegon Sub-district Park and Jombang Park, where plant species with height between 5 to $10 \mathrm{~m}$ reach $29.63 \%, 20.27 \%$, and $17.65 \%$, respectively. Meanwhile, plant species with height greater than $10 \mathrm{~m}$ with a percentage above $10 \%$ were only found in Jombang Sub-district Park (11.76\%). This data shows that several urban parks, such as Children Park, Cilegon Sub-district Park, and Jombang Sub-district Park, already have high tree species above $5 \mathrm{~m}$ with a percentage of more than $10 \%$, meaning that the three urban parks were quite thick with trees. Based on field observations, Children Park and Jombang Sub-district Park showed quite lush parks. Meanwhile, Cilegon Sub-district Park, which was dominated by a sports field, had $20.27 \%$ of tree species with a height of 5 to $10 \mathrm{~m}$, and $28.38 \%$ of shrubs and herbs with a height of less than $1 \mathrm{~m}$. The trees, shrubs, and herbs were planted as a barrier to the urban park.

Vegetation profile was created for each park to find out the vertical structure of vegetation as shown in Figure 6 below. Based on the figure, Children Park, Simpang Park, Cilegon Sub-district Park, and Jombang Sub-district Park had several layers of canopy, while the other urban parks had only one layer. An urban park that has multiple layers of canopy is ecologically very good because it is similar to natural forest which plays a role in protecting the soil from erosion. Based on the canopy layer arranged by the number of individuals, Cilegon Sub-district Park and Jombang Park were better than the other urban parks. Although not ideal, the two parks had multi-layered canopies, although they were still dominated by understorey vegetation with height less than $1 \mathrm{~m}$ tall.

Based on the vegetation profile, it is known that undergrowth of less than $1 \mathrm{~m}$ tall was dominated by $R$. simplex, except in Al-Hadid Park and Purwakarta Subdistrict Park which were dominated by Duranta erecta and Liriope spicata, respectively. Plants with canopy height of 1-2 m were dominated by $S$. paniculatum in Town Square Park, Children Park and Al-Hadid Park; Canna indica dominated Simpang Park, Nurul Ikhlas Park and Cilegon Sub-district Park. Meanwhile, Jombang Sub-district Park was dominated by Plumeria rubra, Hibiscus rosa-sinensis and Yucca aloifolia; and in Purwakarta Sub-district Park Manihot utilissima was found.

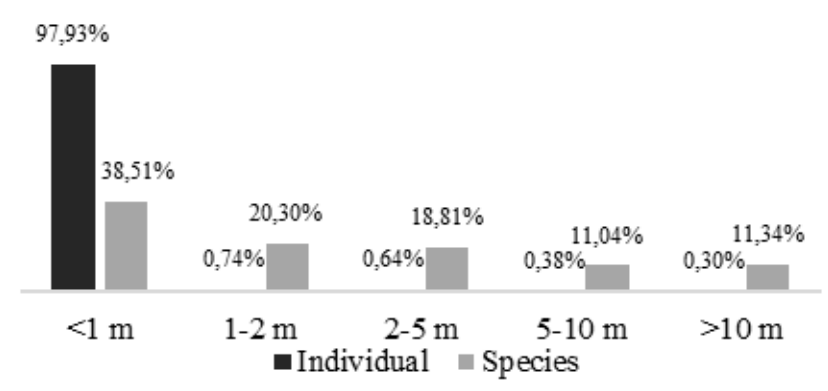

Figure 5. Vegetation composition based on canopy stratification in eight urban parks in Cilegon City, Banten, Indonesia

Table 4. Canopy stratification by individual and species number across the eight urban parks in Cilegon City, Banten, Indonesia

\begin{tabular}{|c|c|c|c|c|c|c|c|c|c|c|c|c|c|c|c|c|}
\hline \multirow{2}{*}{$\begin{array}{l}\text { Canopy } \\
\text { stratification }\end{array}$} & & & \multicolumn{2}{|c|}{5} & \multicolumn{2}{|c|}{4} & \multicolumn{2}{|c|}{5} & & \multicolumn{2}{|c|}{7} & \multicolumn{2}{|c|}{0} \\
\hline & $\% \mathrm{~N}$ & $\% \mathrm{~S}$ & $\% \mathrm{~N}$ & $\% \mathrm{~S}$ & $\% \mathrm{~N}$ & $\% \mathrm{~S}$ & $\% \mathrm{~N}$ & $\% \mathrm{~S}$ & $\% \mathrm{~N}$ & $\% \mathrm{~S}$ & $\% \mathrm{~N}$ & $\% \mathrm{~S}$ & $\% \mathrm{~N}$ & $\% \mathrm{~S}$ & $\% \mathrm{~N}$ & $\% \mathrm{~S}$ \\
\hline$<1 \mathrm{~m}$ & 98.37 & 2 & 3.54 & 51.85 & 99.44 & 62.50 & 94.47 & 94.47 & 96.04 & .71 & 91.56 & 28.38 & 92.77 & 1 & 98.80 & 37.50 \\
\hline & & 2 & & 3 & & 1 & & & 3. & 23 & 0 & 1 & & & & \\
\hline & 14 & 25.0 & 06 & 7.41 & .13 & 14.29 & 0.00 & $0 .($ & 0.0 & 5. & 3.79 & 4 & 1.20 & & 1.16 & 50.00 \\
\hline & 13 & 8.82 & 95 & 29.63 & .10 & 7.14 & 0.33 & 0. & 0.00 & 0.00 & 2.15 & 20.27 & 2.11 & & 0.00 & 0.00 \\
\hline$>10 \mathrm{~m}$ & 0.08 & 5.88 & 0.10 & 7.41 & 0.11 & 5.36 & 4.98 & 4.98 & 0.15 & 5.88 & 1.72 & 8.11 & 0.40 & 11.76 & 0.00 & 0.00 \\
\hline
\end{tabular}

Note: \%N: percent of individual number and \%S: percent of species number; 1. Cilegon Town Square Park; 2. Children Park; 3. Simpang Park; 4. Al-Hadid Park; 5. Nurul Ikhlas Park; 6. Cilegon Sub-district Park; 7 Jombang Sub-district Park; and 8. Purwakarta Sub-district Park 


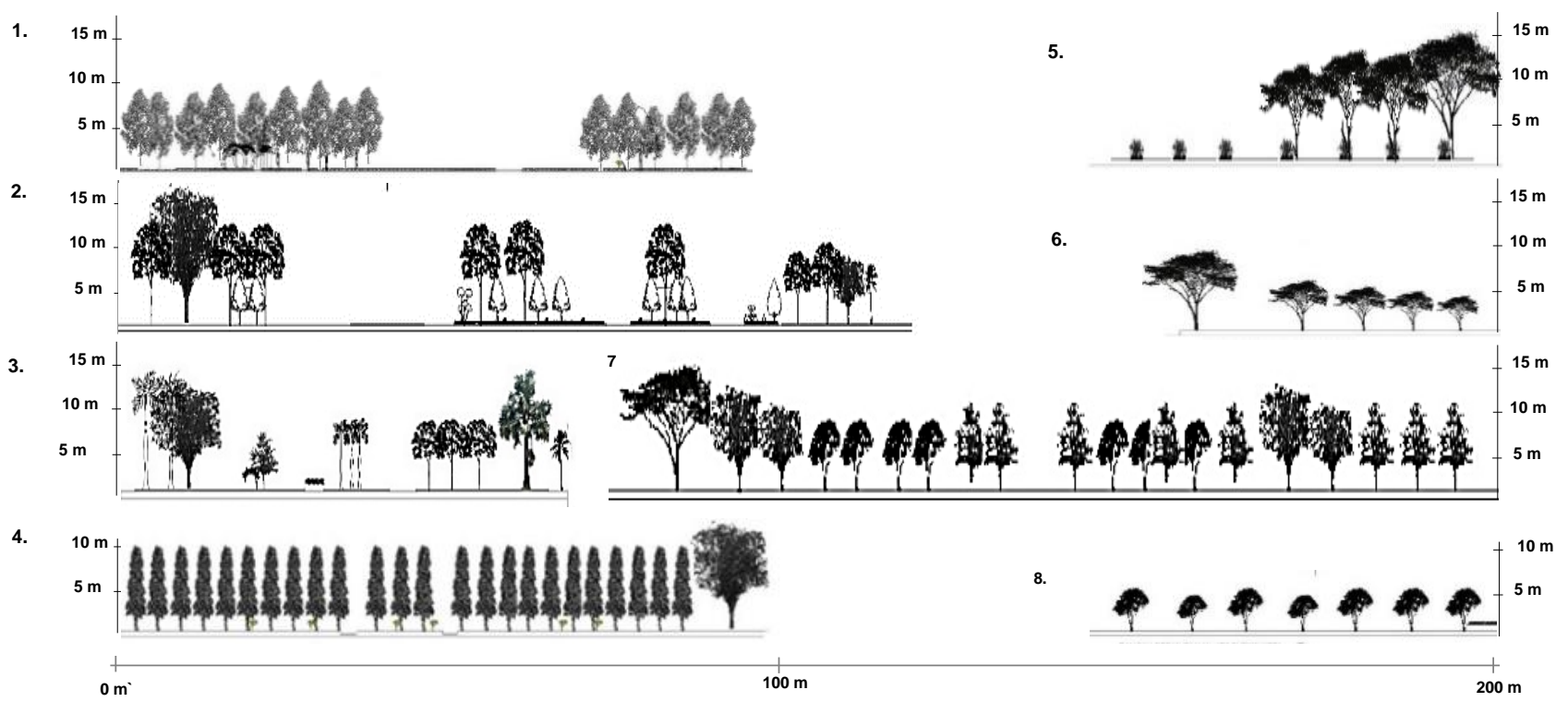

Figure 6. Profile diagram of urban park vegetation in Cilegon City, Banten, Indonesia. 1. Cilegon Town Square Park; 2. Children Park; 3. Simpang Park; 4. Al-Hadid Park; 5. Nurul Ikhlas Park; 6. Cilegon Sub-district Park; 7 Jombang Sub-district Park; and 8. Purwakarta Sub-district Park

Table 5. Stratification diversity index of urban parks in Cilegon City, Banten, Indonesia

\begin{tabular}{lcccccccc}
\hline Parameter & $\mathbf{1}$ & $\mathbf{2}$ & $\mathbf{3}$ & $\mathbf{4}$ & $\mathbf{5}$ & $\mathbf{6}$ & $\mathbf{7}$ & $\mathbf{8}$ \\
\hline The area of the understorey canopy (a) & 20123 & 403 & 5001 & 1362 & 2045 & 3238 & 1003 & 1052 \\
The area of the top plant canopy (b) & 273 & 1754 & 729 & 80 & 402 & 289 & 18797 & 0 \\
Percent (a) (\%) & 99 & 19 & 87 & 94 & 84 & 92 & 5 & 100 \\
Percent (b) (\%) & 1 & 81 & 13 & 6 & 16 & 8 & 95 & 0 \\
Stratification diversity index (H') & 0.056 & 0.486 & 0.386 & 0.227 & 0.440 & 0.279 & 0.199 & 0 \\
\hline
\end{tabular}

Note: \%N:1. Cilegon Town Square Park; 2. Children Park; 3. Simpang Park; 4. Al-Hadid Park; 5. Nurul Ikhlas Park; 6. Cilegon Subdistrict Park; 7 Jombang Sub-district Park; and 8. Purwakarta Sub-district Park

Plants with canopy height of $2-5 \mathrm{~m}$ were found differently in each urban park. In general, the following plants were found Eucalyptus deglupta, Carica papaya, Erythrina crista-galli, Cordyline australis, Wodyetia bifurcata, Bauhinia blakeana, Alstonia scholaris, and $P$. indicus. Whereas at a plant height of 5-10 m there were $E$. deglupta, Cocos nucifera, Swietenia mahagoni, Roystonea regia, Tectona grandis, Samanea saman, Delonix regia, Terminalia mantaly, Ficus benjamina, and Melaleuca quinquenervia.

Plants with canopy height above $10 \mathrm{~m}$ were distinct characteristic of each urban park, i.e., in Town Square Park there were Roystonea regia and Areca catechu; in Children Park there were P. indicus and Ficus lyrata; in Simpang Park, there was Bismarckia nobilis; in Al-Hadid Park there was Polyalthia longifolia; in Nurul Ikhlas Park and Jombang Sub-district Park there was Samanea saman; and in Cilegon Sub-district Park there was Delonix regia. There was none found in Purwakarta sub-district park.

The calculation on stratification diversity index is presented in Table 5. Children Park had the highest stratification diversity index with a value of 0.486 ., while the lowest was Town Square Park with an index value of 0.056. Meanwhile, the Purwakarta Sub-district Park had zero indexes because there was only one layer of stratification. The stratification diversity index has a positive correlation with species diversity index of birds or insects. If the stratification diversity index is high, the diversity index for bird or insect species is also high (Iskandar 2017). Urban parks that have a high number of plant species and a high diversity index will provide ecosystem services for insect and bird habitats. They also reduce the risk of soil erosion because the kinetic power of rainwater before it hits the soil surface can be held back by various layers of the canopy. In addition, a lush urban park with lots of litter and compost is important for maintaining soil fertility (Sarah et al. 2015).

\section{Plant function perceived by the residents}

The results of interviews with residents of Cilegon City demonstrated that they were quite familiar with all urban parks in Cilegon including several small parks and those that were built by private companies. The top three most recognized parks were Town Square Park, Children Park, and Jombang Park; and the most visited urban parks were Town Square Park, Children Park and Simpang Park. These three parks were frequently visited because of their location in the administrative center of Cilegon City. 
The residents understood well the function of city parks as green open spaces and city lungs that absorb carbondioxide, produce oxygen and reduce air pollution. The parks also make city aesthetic, improve the coolness of local temperature, and provide recreational facilities, playground, and other social activities. The benefits of parks that were felt most by residents were beautifying the city, recreational facilities, and as the lungs of the city.

Some residents stated that the quality of the urban parks in Cilegon City was still not good (51\%), more than a quarter said it was good $(29 \%)$, and others said it was enough $(20 \%)$. The things that many residents complained about were facilities, maintenance, the amount and diversity of vegetation. The residents' assessment of the quality of the urban park can be grouped into facilities, accessibility, vegetation and functions. According to the population, these criteria are as shown in Table 6.

The knowledge regarding the function of the urban park and the plants in the urban park is important. Figure 7 shows the proportion of the knowledge on the function of plants in the urban park from 50 respondents. The figure shows that the main functions of plants in the park were dominated by ornamental plants rather than shade plants and directed plants. This is in line with the vegetation structure which is mostly dominated by shrubs and herbs which act as ornamental plants rather than tree plants. But for the other functions of plants in urban parks, many residents do not know the uses. Nevertheless, from plants whose functions are known, most people know plants as medicine. In addition, the portion of plant functions known to the population is timber, vegetable and seasoning, and fruit, respectively. The limited knowledge of the residents regarding the uses of plants is likely due to most plants in the parks were non-native plants. Residents often see plants in various locations in the park, but are not familiar with the names and functions of the plant.

The results from the interviews with residents show that the types of plants that can be used as edible fruit, medicinal, vegetable and seasoning, and timber are as shown in Table 7.

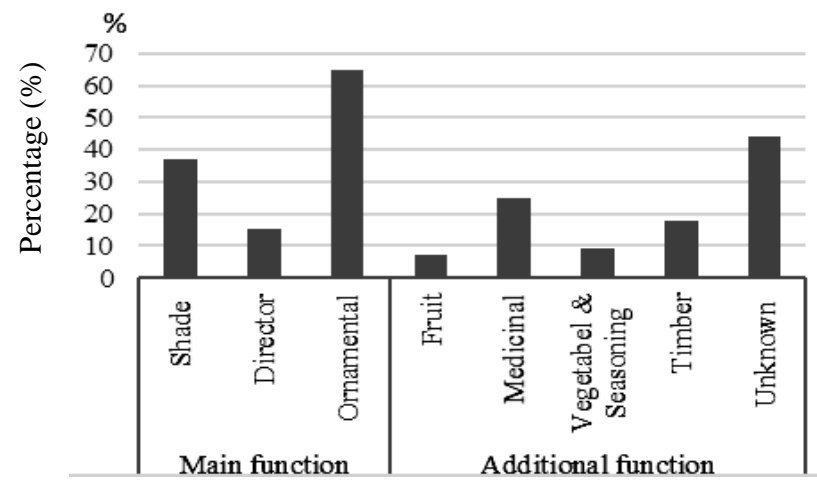

Figure 7. The perception of the residents of Cilegon City, Banten, Indonesia regarding the function/use of the plants in the urban parks

Table 6. The perception of the residents of Cilegon City, Banten, Indonesia on urban park quality based on four criteria

\begin{tabular}{llll}
\hline Facilities & Accessibility & Vegetation & Function \\
\hline $\begin{array}{l}\text { Condition: Completeness, cleanliness, } \\
\text { orderly, neatly, healthy, and secure }\end{array}$ & $\begin{array}{l}\text { Strategic location, and } \\
\text { noise-free }\end{array}$ & $\begin{array}{l}\text { High diversity, shade plant, } \\
\text { and ornamental plant, }\end{array}$ & $\begin{array}{l}\text { Recreation, education, sport, } \\
\text { entertainment, culinary, play, } \\
\text { Amenities: Playing ground, parking area, }\end{array}$ \\
$\begin{array}{l}\text { CCTV, Free Wifi, education area, and } \\
\text { sport facilities }\end{array}$ & & & photoghy spot, and social \\
interaction
\end{tabular}

Tabel 7. The use of plant species found in urban parks in Cilegon City, Banten, Indonesia based on the knowledge of the residents

\begin{tabular}{llll}
\hline Edible fruit & Medicinal & $\begin{array}{l}\text { Vegetable and } \\
\text { seasoning }\end{array}$ & Timber \\
\hline Areca catechu, & Alternanthera brassiliana, Areca catechu, & Carica papaya, & Acacia auriculiformis, Alstonia \\
Artocarpus communis & Catharanthus roseus, Calotropis gigantea, Canna & Cnidoscolus & scholaris, Casuarina \\
Carica papaya, & indica, Carica papaya, Cocos nucifera, Cosmos & aconitifolius, & equisetifolia, Cocos nucifera, \\
Chrysophyllum & sulphureus, Delonix regia, Elaeis guineensis, & Cosmos sulphureus,, & Delonix regia, Eucalyptus \\
cainito Cocos & Erythrina variegata, Eupatorium capillifolium, & Cocos nucifera,, & deglupta, Ficus lyrate, \\
nucifera, & Euphorbia lactea, Euphorbia milii, Erythrina & Elaeis guineensis, & Filicium decipiens, \\
Ficus benjamina, & crista-galli, Eucalyptus deglupta, Excoecaria & Helianthus annuus, & Lagerstroemia speciosa, \\
Mangifera indica, & cochinchinensis, Hibiscus rosa-sinensis, Jasminum & Manihot utilissima, & Mangifera indica, Melia \\
Psidium guajava, & sambac, Lantana urticoides, Leucaena & Tectona grandis, & azedarach, Pterocarpus \\
& leucocephala, Melaleuca quinquenervia, Plumeria & & indicus, Peltophorum \\
& rubra, Portulaca grandiflora, Psidium guajava, & & Talipariti tiliaceum, \\
& Pterocarpus indicus, Ruellia simplex, Senna alata,, & & Terminalia catappa, Tectona \\
& Sansevieria trifasciata, Solanumpseudocapsicum, & & grandis, Swietenia mahagoni, \\
& Swietenia mahagoni & & Streblus asper \\
\hline
\end{tabular}


Plants in urban parks that can be used as edible fruits are plants that often found in homegarden. The exception is $F$. benjamina fruit which is not commonly eaten by most people but is actually edible fruit. This is in line with the study stating that the $F$. benjamina fruit was edible but not cultivated as a source of antioxidants and high nutritional value, particularly potassium (Rai et al. 2005; Aloanis and Karundeng 2019; Pasha and Uddin 2019). In addition, there is Areca catechu, an edible fruit commonly used to eat with betel (Pepper betel), a culture from various regions in Indonesia (Iskandar and Iskandar 2017; Dwinanto et al. 2019), including in the City of Cilegon. There were also those who used areca nut to eat with betel, although it was limited to elderly women.

The knowledge of the residents of Cilegon City regarding the medicinal uses of plants in urban park is presented in Table 8 . In general, the knowledge of the residents about medicinal plants was limited to the use of plants for common diseases such as skin diseases, digestive system, respiratory system, and parasitic diseases. These findings have several similarities with other studies conducted in various regions in Indonesia (Silalahi et al. 2015; Malini et al. 2017; Indriwati and Suhadi 2018; Rahmawati et al. 2020)

Urban park plants that were used by the residents as vegetables were $C$. papaya, Cnidoscolus aconitifolius, $C$. sulphureus, and M. utilissima. The leaves of these plants were used for vegetables. In addition, the leaves shoots of teak plants were used as food coloring of the culinary 'gudeg' which is a characteristic of traditional Jogja culture (Harmayani et al. 2019). Besides coconut milk, C. nucifera was also used to make vegetable oils. Meanwhile, the common use of Elaeis guineensis and Helianthus annuus was for cooking oils.

The residents of Cilegon City also knew a lot about the plants in the urban park as timber. Of the 19 plants whose benefits were known as timber, there were several plants that were the durable wood-producing plants, namely $P$. indicus, T. grandis and Swietenia mahagoni (Hidayat et al. 2014; Jasni 2016).

Table 8. Plants in urban parks in Cilegon City, Banten, Indonesia with medicinal uses based on residents knowledge

\begin{tabular}{|c|c|c|c|c|c|}
\hline Species name & Local name & Part used & Illness & Preparative methods & Prescriptive methods \\
\hline Alternanthera brassiliana & Bayam dempo & Leaf & Bruises & Pounding & Topical application \\
\hline Areca catechu & Pinang & Seed & Worms & Decocting & Oral ingestion \\
\hline Canna indica & Bunga tasbih & Rhizome & Fever & Decocting & Oral ingestion \\
\hline Catharanthus roseus & Tapak dara & Flower & Diabetes mellitus & Decocting & Oral ingestion \\
\hline Carica papaya & Pepaya & Leaf & Hypertension & Decocting & Oral ingestion \\
\hline Cocos nucifera & Kelapa & Coconut water & Fever & Decocting & Oral ingestion \\
\hline Cosmos sulphureus & Kenikir & Leaf & Gastritis & Decocting & Oral ingestion \\
\hline Delonix regia & Flamboyan & Leaf & Inflamation & Decocting & Oral ingestion \\
\hline Elaeis guineensis & Kelapa sawit & Palm oil & Burns & Processed & Topical application \\
\hline Erythrina crista-gali & Dadap merah & Leaf & Worms & Decocting & Oral ingestion \\
\hline Erythrina variegata & Dadap & Leaf & Inflammation & Decocting & Oral ingestion \\
\hline Eupatorium capillifolium & Adas Hutan & Leaf & Dysentery & Decocting & Oral ingestion \\
\hline Euphorbia lactea & Tulang naga & Gum & Inflammation & Pounding & Topical application \\
\hline Euphorbia milii, & Pakis giwang & Gum & Toothache & None & Topical application \\
\hline Eucalyptus deglupta, & Pohon pelangi & Leaf & Respiratory disease & Distillation & Inhalation \\
\hline Excoecaria cochinchinensis & Sambang Darah & Leaf & Dysentery & Decocting & Oral ingestion \\
\hline Hibiscus rosa-sinensis & Kembang sepatu & Flower & Painful menstruation & Decocting & Oral ingestion \\
\hline Jasminum sambac & Melati & Flower & Stomach & Decocting & Oral ingestion \\
\hline Lantana urticoides & Cente & Leaf & Bruises & Punding & Topical application \\
\hline Leucaena leucocephala, & Lamtoro & Seed & Worms & None & Oral application \\
\hline Maelaleuca quinquenervia, & Kayuputih & Leaf & Respiratory disease & Distilation & Inhalation \\
\hline Plumeria rubra & Kamboja & Gum & Toothache & None & Topical application \\
\hline Portulaca grandiflora, & Krokot & Leaf & Hemorrhoids & Decocting & Oral ingestion \\
\hline Psidium guajava & Jambu bate & Shoots & Stomach, diarrhea & Pounding, squeezing & Oral ingestion \\
\hline Pterocarpus indicus, & Angsana & Gum & Toothache, sprue & None & Topical application \\
\hline Ruellia simplex & Kencana Ungu & Flower & Itch & Pounding & Topical application \\
\hline Senna alata, & Ketepeng & Leaf & Tinea versicolor & Pounding & Topical application \\
\hline Sansevieria trifasciata, & Lidah mertua & Leaf & Diabetes & Decocting & Oral Ingestion \\
\hline Solanum pseudocapsicum, & Cherry Jerusalem & Leaf, fruit & Boils & Pounding & Topical application \\
\hline Swietenia mahagoni & Mahoni & Seed & Malaria & None & Oral ingestion \\
\hline
\end{tabular}

Note: For preparative methods, decocting: extract part of plant with or without heating; pounding: crushed parts of plant; processed: processing part of the plant into a product; squeezing: extraction part of plant with or without water; destination: purifying extract of plant by a process of heating and cooling; none: use of part of plant without treatment. 
In summary, urban parks in Cilegon City consisted of 114 species and 46 families, which can be considered fairly high compared to the number of species found in a wider area around it. However, the diversity and species richness tended to be low and the vegetation communities were unstable. In addition, the vegetation was dominated primarily by non-native and invasive tree species. The stratification index generally had low strata which were represented by plants with height of less than 1 meter, such as $R$. simplex and $S$. paniculatum. On the other hand, the function of the plants that occurred in the urban parks in Cilegon City was dominated by ornamental plants rather than ecological functions and human needs. This fact indicates that urban parks in the study area have still low ecosystem services. This is in line with the opinion of the residents who think that the quality of the urban park in Cilegon City was still not good, hence they need some improvement in order to provide more ecosystem functions and to be more enjoyable for the residents.

\section{ACKNOWLEDGEMENTS}

The authors give appreciation and thanks to the Government of Cilegon City, Banten, Indonesia especially Head of Housing and Settlement Areas and Herna Purnama as Head of the Section for Urban Maintenance of Facilities and Architecture of Cilegon City, who have given permission to collect research data in the urban parks.

\section{REFERENCES}

Agrawal A, Gopal K. 2013. Application of diversity index in measurement of species diversity. In: Biomonitoring of Water and Waste Water. Springer, India. DOI: 10.1007/978-81-322-0864-8.

Akmar N, Aziz A, Nillson K. 2018. Recreational use of urban green space in Malaysian cities. Intl J Bus Soc 19 (2010): 1-16.

Aloanis AA, Karundeng M. 2019. Total kandungan antioksidan ekstrak etanol buah beringin (Ficus benjamina Linn.). Fuller. J Chem 4 (1): 14. DOI: $10.37033 /$ fjc.v4i1.45.

Amos KC, Maloy M. 2015. The role of urban parks in environmental education: How Mantled Howler Monkeys (Alouatta palliata) can increase social outreach. The Parque Natural Metropolitano, Panama.

Azani N, Babineau M, Bailey CD, Banks H, Barbosa AR, Pinto RB, Boatwright JS, Borges LM, Brown GK, Bruneau A, Candido E, Cardoso D, Chung KF, Clark RP, Conceição ADS, Crisp M, Cubas P, Delgado-Salinas A, Dexter KG, et al. 2017. A new subfamily classification of the Leguminosae based on a taxonomically comprehensive phylogeny. Taxon 66 (1): 44-77. DOI $10.12705 / 661.3$

Bagheri Z, Nadoushan MA, Abari MF. 2017. Evaluation of the effect of green space on air pollution dispersion using satellite images and landscape metric: a case study of Isfahan City. Fresenius Environ Bull 26 (12A): 8135-8145.

Beech E, Rivers M, Oldfield S, Smith PP. 2017. Global tree search: The first complete global database of tree species and country distributions. J Sustain For 36 (5): 454-489. DOI: 10.1080/10549811.2017.1310049

Brtnický M, Pecina V, Hladký J, Radziemska M, Koudelková Z, Klimánek M, Richtera L, Adamcová D, Elbl J, Galiová MV, Baláková L, Kynický J, Smolíková V, Houška J, Vaverková MD. 2019. Assessment of phytotoxicity, environmental and health risks of historical urban park soils. Chemosphere 220: 678-686. DOI 10.1016/j.chemosphere.2018.12.188.

Burghardt KT, Tallamy DW, Gregory Shriver W. 2009. Impact of native plants on bird and butterfly biodiversity in suburban landscapes.
Conserv Biol 23 (1): 219-224. DOI: 10.1111/j.15231739.2008.01076.x

Carey JJ, Delaney MF. 2010. T-scores and Z-scores. Clin Rev Bone Miner Metab 8 (3): 113-121. DOI: 10.1007/s12018-009-9064-4.

Chen S, Wang W, Xu W, Wang Y, Wan H, Chen D, Tang Z, Tang X, Zhou G, Xie Z, Zhou D, Shangguan Z, Huang J, He JS, Wang Y, Sheng J, Tang L, Li X, Dong M, Wu Y, Wang Q, Wang Z, Wu J, Chapin III S, Bai Y. 2018. Plant diversity enhances productivity and soil carbon storage. Proc Natl Acad Sci 115 (16): 4027-4032. DOI: 10.1073/pnas.1700298114.

Cole HVS, Triguero-mas M, Connolly JJT, Anguelovski I. 2019. Determining the health benefits of green space: Does gentrification matter? Health Place 57: 1-11. DOI: 10.1016/j.healthplace.2019.02.001.

Cundaningsih N, Husodo T, Hadikusumah HY. 2015. Carbon sinks of morphologic tree stand in Bandung City Green Space: Case study Taman Balai Kota, Kebun Binatang. The 5th International Seminar on New Paradiom and Innovation on Natural Sciences and Its Application (5th ISNPINSA), 7-8 October 2015, Semarang, Indonesia

Dash S, Mandal U, Parida S, Mahalik G. 2019. Studies on the use of plants and plant parts in Ganesh Puja for worshipping of the Lord Ganesha in Odisha, India. Intl J Adv Sci Technol 28 (13): 63-71.

Dearborn DC, Kark S. 2010. Motivations for conserving urban biodiversity. Conserv Biol 24 (2): 432-440. DOI: 10.1111/j.15231739.2009.01328.x

Dwinanto A, Soemarwoto RS, Palar MRA. 2019. Betel Pinang culture and its preservation opportunities in West Sumba, Indonesia. Patanjala J Penelitian Sejarah dan Budaya 11 (3): 363-380. DOI: 10.30959/patanjala.v11i3.543. [Indonesian]

Eisenhauer N, Hines J, Isbell F, van der Plas F, Hobbie SE, Kazanski CE, Lehmann A, Liu M, Lochner A, Rillig MC, Vogel A, Worm K, Reich PB. 2018. Plant diversity maintains multiple soil functions in future environments. Elife 7: e41228. DOI: 10.7554/eLife.41228.

Erdianto AR, Irwan SNR, Kastono D. 2019. The ecological function of the Denggung Sleman Park vegetation is to control the microclimate and reduce noise. Vegetalika 8 (3): 139-152. DOI: 10.22146/veg.41374. [Indonesan]

Ezcurra C, Daniel TF. 2007. Ruellia simplex, an older and overlooked name for Ruellia tweediana and Ruellia coerulea (Acanthaceae). Darwiniana 45 (2): 201-203. DOI: 10.14522/darwiniana.2014.452.92.

Gamito S. 2010. Caution is needed when applying Margalef diversity index. Ecol Indic 10 (2): 550-551. DOI: 10.1016/j.ecolind.2009.07.006.

Goddard MA, Dougill AJ, Benton TG. 2010. Scaling up from gardens: biodiversity conservation in urban environments. Trends Ecol Evol 25 (2): 90-98. DOI: 10.1016/j.tree.2009.07.01.6.

Gomes G, Silva G, Silva D, Oliveira R, Conceição G. 2018. Botanical composition of Fabaceae family in the Brazilian Northeast, Maranhão, Brazil. Asian J Environ Ecol 6 (4): 1-10. DOI: 10.9734/ajee/2018/41207.

Harmayani E, Gardjito M, Santoso U. 2019. Traditional Indonesian food series. In: Prabowo MSP, Sari PM (eds) Series 1). Gadjah Mada University Press, Yogyakarta. [Indonesian]

Hidayat IW, Kurnita NI. 2018. Inventory of Indonesian native montane trees for environmental support and space ornaments in Cibodas Botanical Garden. IOP Conf Ser Earth Environ Sci 203: 012017. DOI: 10.1088/1755-1315/203/1/012017.

Hidayat W, Kim YK, Jeon WS, Lee JA, Kim AR, Park SH, Maail RS, Kim NH. 2014. Qualitative and quantitative anatomical characteristics of four tropical wood species from Moluccas, Indonesia. J Korean Wood Sci Technol 45 (4): 467-476.

Indriwati SE, Suhadi LN. 2018. Character education development through bioprospecting of medicinal plants in Indonesian national park. Opcion 34 (15): 1632-1649.

Irsyam ASD, Hariri MR. 2016. Eupatorium capilifolium (Lam.) Small ex Porter \& Britton (Asteraceae: Eupatorieae), New record for Javanese $\begin{array}{lllll}\text { flora. Al-Kauniyah J Biol } 9 & \text { (2): 80-86. DOI: }\end{array}$ 10.15408/kauniyah.v9i2.3335.

Iskandar J. 2017. Ornitology and Etnoornitology. Plantaxia, Yogyakarta. [Indonesian]

Iskandar J, Iskandar B. 2016. Plant architecture: structure of village homegarden and urban green space. Teknosain, Yogyakarta [Indonesian]

Iskandar J, Iskandar BS. 2017. Various plants of traditional rituals: Ethnobotanical research among the Baduy community. Biosaintifika J Biol Biol Educ 9 (1): 114-125. DOI: 10.15294/biosaintifika.v9i1.8117 
Iskandar J, Iskandar BS. 2018. Ethnoecology, rice biodiversity and modernization of rice cultivation: a case study in Baduy and Kampung Naga communities. J Biodjati 3 (1): 47-62. DOI: 10.15575/biodjati.v3i1.2344. [Indonesian]

Janhall S. 2015. Review on urban vegetation and particle air pollutionDeposition and dispersion. Atmos Environ 105: 130-137. DOI 10.1016/j.atmosenv.2015.01.052.

Jasni. 2016. Natural durability of 57 types of Indonesian wood by testing under the shade. Jurnal Penelitian Hasil Hutan 34 (3): 179-188. DOI: 10.20886/jphh.2016.34.3.179-188. [Indonesian]

Jones KR. 2018. 'The lungs of the city': Greenspace, public health and bodily metaphor in the landscape of urban park history. Environ Hist Camb 24 (1): 39-58. DOI: 10.3197/096734018X15137949591837.

Kabisch N, van den Bosch M, Lafortezza R. 2017. The health benefits of nature-based solutions to urbanization challenges for children and the elderly-A systematic review. Environ. Res. 159: 362-373. DOI: 10.1016/j.envres.2017.08.004.

Karyati, Adhi MA. 2018. Types of Understorey in the Educational Forest of The Faculty of Forestry, Mulawarman University. Mulawarman University Press, Samarinda. [Indonesian]

Klein JM. 2018. Environmental education in urban green space: Understanding educator practice. Lesley University, Cambridge, MA.

Lacy P De, Shackleton C. 2017. Aesthetic and spiritual ecosystem services provided by urban sacred sites. Sustainability 9: 1628. DOI: $10.3390 / \mathrm{su} 9091628$.

Lange M, Eisenhauer N, Sierra CA, Bessler H, Engels C, Griffiths RI, Mellado-Vázquez PG, Malik AA, Roy J, Scheu S, Steinbeiss S, Thomson BC, Trumbore SE, Gleixner G. 2015. Plant diversity increases soil microbial activity and soil carbon storage. Nat Commun 6: 6707. DOI: $10.1038 /$ ncomms 7707 .

Leeuwen E Van, Nijkamp P, Vaz TDN. 2010. The multifunctional use of urban greenspace. Intl J Agric Sustain 8 (1 \& 2): 20-25. DOI: 10.3763/ijas.2009.0466.

Leimer S, Kreutziger Y, Rosenkranz S, Beßler H, Engels C, Hildebrandt A, Oelmann Y, Weisser WW, Wirth C, Wilcke W. 2014. Plant diversity effects on the water balance of an experimental grassland. Ecohydrology 7 (5): 1378-1391. DOI: 10.1002/eco.1464.

Lepczyk CA, Aronson MFJ, Evans KL, Goddard MA, Lerman SB. 2017. Biodiversity in the city: Fundamental questions for understanding the ecology of urban green spaces for biodiversity conservation. Bioscience 67 (9): 799-807. DOI: 10.1093/biosci/bix079.

Leslie AD, Wilson ER. 2009. The anatomy of a woodland: Stand profile diagrams as an aid to problem-based learning in undergraduate forestry education. For Chron 85 (5): 725-732. DOI: $10.5558 / \mathrm{tfc} 85725-5$.

Lestari G, Program M, Arsitektur S, Gunawan A, Pengajar S, Arsitektur D. 2010. The effect of tree canopy shape. J Lanskap Indonesia 2 (1) 30-35. DOI: $10.29244 /$ jli.2010.2.1.\%25p. [Indonesian]

Li W, Ouyang Z, Meng X, Wang X. 2006. Plant species composition in relation to green cover configuration and function of urban parks in Beijing, China. Ecol Res 21 (2): 221-237. DOI: 10.1007/s11284-0050110-5.

Malini DM, Madihah, Kusmoro J, Kamilawati F, Iskandar J. 2017. Ethnobotanical study of medicinal plants in Karangwangi, District of Cianjur, West Java. Biosaintifika J Biol Biol Educ 9 (2): 345-356. DOI: 10.15294/biosaintifika.v9i2.5756.

Manes F, Incerti G, Salvatori E, Vitale M, Ricotta C, Costanza R. 2012. Urban ecosystem services: Tree diversity and stability of tropospheric ozone removal. Ecol. Appl. 22 (1): 349-360. DOI: 10.1890/110561.1.

Markevych I, Schoierer J, Hartig T, Chudnovsky A, Hystad P, Dzhambov AM, de Vries S, Triguero-Mas M, Brauer M, Nieuwenhuijsen MJ, Lupp G, Richardson EA, Astell-Burt T, Dimitrova D, Feng X, Sadeh M, Standl M, Heinrich J, Fuertes E. 2017. Exploring pathways linking greenspace to health: Theoretical and methodological guidance. Environ Res 158: 301-317. DOI: 10.1016/j.envres.2017.06.028.

Miller RW, Hauer RJ, Werner LP. 1988. Urban Forestry: Planning and Managing Urban Greenspaces. Prentice-Hall, New York.

Mueller-Dombois D, Ellenberg H. 1974. Aims and Methods of Vegetation Ecology (10th ed.). John Wiley \& Sons. DOI: 10.2307/213332.

Muhlisin M. 2016. Quality of urban green open space and its use in several districts/cities in Banten province. J Litbangda 8 (1): 1-11.

Muratet A, Pellegrini P, Dufour AB, Arrif T, Chiron F. 2015. Perception and knowledge of plant diversity among urban park users. Landsc Urban Plan 137: 95-106. DOI: 10.1016/j.landurbplan.2015.01.003
Nagendra H, Gopal D. 2010. Tree diversity, distribution, history and change in urban parks: Studies in Bangalore, India. Urban Ecosyst 14 (2): 211-223. DOI: 10.1007/s11252-010-0148-1

Nielsen AB, van den Bosch M, Maruthaveeran S, van den Bosch CK. 2014. Species richness in urban parks and its drivers: A review of empirical evidence. Urban Ecosyst 17 (1): 305-327. DOI: 10.1007/s11252-013-0316-1

NSW Office of Environment and Heritage. 2012. National recovery plant, magenta lilly pilly (Syzygium paniculatum). in species profile and threats Database (Issue June). NSW Office of Environment and Heritage, Australian Government. http://www.environment.gov.au/cgibin/sprat/public/publicspecies.pl?taxon_id=20307

Odum EP. 1993. Fundamentals of Ecology, 4th ed. WB Sunder's Co, New York.

Odum EP, Baret GW. 1972. Fundamentals of Ecology. Holt, Rinehart and Winston, New York. DOI: 10.2307/3799291

Ogedegbe A, Ikhajiagbe B, Anoliefo GO. 2013. Growth response of Alternanthera brasiliana ( L .) Kuntze in a Waste engine oil-polluted soil. Trends Eng Appl Sci 4 (2): 322-327.

Okunlola AI, Adepoju AO, Agele SO. 2016. Air Pollution Tolerance Index (APTI) and carbon sequestration of selected trees and shrubs for urban development in Akure Ondo State, Southwest Nigeria. Braz J Biol Sci 3 (6): 395-405. DOI: 10.21472/bjbs.030615

Partomihardjo T, Arifiani D, Pratama BA, Mahyuni R. 2014. Important Tree Species in Nusakambangan Foreest (Lani Rachm). LIPI Press. [Indonesian]

Palliwoda J, Kowarik I, von der Lippe M. 2017. Human-biodiversity interactions in urban parks: The species level matters. Landsc. Urban Plan. 157 (2017): 394-406. DOI: 10.1016/j.landurbplan.2016.09.003

Pasha MK, Uddin SB. 2019. Minor edible fruits of Bangladesh. Bangladesh J. Plant Taxon 26 (2): 299-313. DOI: 10.3329/bjpt.v26i2.44596

Pearse WD, Cavender-Bares J, Hobbie SE, Avolio ML, Bettez N, Roy Chowdhury R, Darling LE, Groffman PM, Grove JM, Hall SJ, Heffernan JB, Learned J, Neill C, Nelson KC, Pataki DE, Ruddell BL, Steele MK, Trammell TLE. 2018. Homogenization of plant diversity, composition, and structure in North American urban yards: 9 (2): e02105. DOI: $10.1002 / \mathrm{ecs} 2.2105$

Pulighe G, Fava F, Lupia F. 2016. Insights and opportunities from mapping ecosystem services of urban green spaces and potentials in planning. Ecosyst. Serv. 22(2016): 1-10. DOI: 10.1016/j.ecoser.2016.09.004

Rahmawati N, Mustofa FI, Haryanti S. 2020. Diversity of medicinal plants utilized by to Manui ethnic of Central Sulawesi, Indonesia. Biodiversitas 21 (1): 375-392. DOI: 10.13057/biodiv/d210145

Rai AK, Sharma RM, Tamang JP. 2005. Food value of common edible wild plants of Sikkim. J Hill Res 18 (2): 99-103.

Raina AK, Bala C. 2011. Effect of vehicular pollution on Duranta repens L. in Jammu City. J Appl Nat Sci 3 (2): 211-218. DOI: 10.31018/jans.v3i2.181

Ramírez F, Kallarackal J. 2019. The phenology and potential ecological associations of Magenta Lilly Pilly (Syzygium paniculatum Gaertn) a native vulnerable Australian tree growing in Bogotá, Colombia. Arboric J 41 (4): 191-211. DOI: 10.1080/03071375.2019.1642047

Reid CE, Clougherty JE, Shmool JLC, Kubzansky LD. 2017. Is all urban green space the same? A comparison of the health benefits of trees and grass in New York City. Environ Res Public Health 74 (1411): 118. DOI: $10.3390 /$ ijerph 14111411

Rózová Z, Supuka J, Klein J, Jasenka M, Tóth A, Štefl L. 2020. Effect of vegetation structure on urban climate mitigation. Acta Hortic Regiotect 23 (2): 60-65. DOI: 10.2478/ahr-2020-0013

Sarah P, Zhevelev HM, Oz A. 2015. Urban park soil and vegetation: Effects of natural and anthropogenic factors. Pedosphere 25 (3): 392404. DOI: $10.1016 / \mathrm{S} 1002-0160(15) 30007-2$

Schipperijn JJ. 2010. Use of urban green space. Forest \& Landscape Research No. 45-2010. Forest \& Landscape Denmark.

Sellers BA, Devkota P, Ferrell JA. 2019. Dogfennel (Eupatorium capillifolium): Biology and control.

Shan X. 2014. Socio-demographic variation in motives for visiting urban green spaces in a large Chinese city. Habitat Int 41: 114-120. DOI: 10.1016/j.habitatint.2013.07.012

Silalahi M, Supriatna J, Walujo EB, Nisyawati. 2015. Local knowledge of medicinal plants in sub-ethnic Batak Simalungun of North Sumatra, $\begin{array}{lllll}\text { Indonesia. } & \text { Biodiversitas } 16 & \text { (1): } & \text { 44-54. DOI: }\end{array}$ 10.13057/biodiv/d160106 
Smith AM, Adams R, Wilson SB. 2014. Mexican-petunia (Ruellia simplex) invasions: Management challenges and research opportunities. Wildland Weeds 16: 20-23.

Smith WS, da Silva FL, de Amorim SR, Stefani MS. 2018. Urban biodiversity: how the city can do its management? Biodivers Intl J 2 (2): 246-251. DOI: 10.15406/bij.2018.02.00068.

Soerianegara I, Indrawan A. 1978. Indonesian Forest Ecology. Departemen Manajemen Hutan Fakultas Kehutanan, IPB. Bogor, Indonesia. [Indonesian]

Spellerberg IANF, Fedor PJ. 2003. A tribute to Claude Shannon (19162001) and a plea for more rigorous use of species richness, species diversity and the 'Shannon-Wiener' Index. Glob Ecol Biogeogr 12 (3): 177-179. DOI: $10.1046 / \mathrm{j} .1466-822 X .2003 .00015 . \mathrm{x}$

Suin MN. 2002. Metoda Ekologi. Universitas Andalas, Padang. [Indonesian]

Sujarwo W, Caneva G, Zuccarello V. 2020. Patterns of plant use in religious offerings in Bali (Indonesia). Acta Bot Bras 34 (1): 40-53. DOI: 10.1590/0102-33062019abb0110.

Sukarya DG, Witono JR, Sukarya K, Safarinanugraha D, Setyanti D, Wati RK, Hardstaff LK. 2013. 3500 Plant Species of the Botanic Gardens of Indonesia. PT Sukarya \& Sukarya Pandetama, Bogor. [Indonesian]

Sukewijaya I, Kohdrata N. 2015. Study of the characteristics of the Gumi Banten plant for roadside tree landscaping. Bumi Lestari 15 (2): 147 164. [Indonesian]

Sutrisno IH, Akob B, Navia ZI, Nuraini, Suwardi AB. 2020. Documentation of ritual plants used among the Aceh tribe in Peureulak, East Aceh District, Indonesia. Biodiversitas 21 (11): 4990 4998. DOI: $10.13057 /$ biodiv/d211102.

Tabanca N, Bernier UR, Tsikolia M, Becnel JJ, Sampson B, Werle C, Demirci B, Başer KHC, Blythe EK, Pounders C, Wedge DE. 2010 Eupatorium capillifolium essential oil: Chemical composition, antifungal activity, and insecticidal activity. Nat Prod Commun 5 (9): 1409-1415. DOI: 10.1177/1934578x1000500913.

Taek MM, Banilodu L, Neonbasu G, Watu YV, E.W. BP, Agil M. 2019. Ethnomedicine of Tetun ethnic people in West Timor Indonesia: philosophy and practice in the treatment of malaria. Integr Med Res 8 (3): 139-144. DOI: 10.1016/j.imr.2019.05.005.

Talal ML, Santelmann MV. 2019. Plant community composition and biodiversity patterns in urban parks of Portland, Oregon. Front Ecol Evol 7: 1-16. DOI: 10.3389/fevo.2019.00201

Talal ML, Santelmann M V. 2020. Vegetation management for urban park visitors: a mixed methods approach in Portland, Oregon. Ecol Appl 30 (4): e02079. DOI: 10.1002/eap.2079.

Taylor KT, Maxwell BD, Pauchard A, Nuñez MA, Rew LJ. 2016. Native versus non-native invasions: Similarities and differences in the biodiversity impacts of Pinus contorta in introduced and native ranges. Divers Distrib 22 (5): 578-588. DOI: 10.1111/ddi.12419.
Thomas A. 2011. Field guide for identifying forest tree species, Kalimantan Forests and Climate Partnership (KFCP). IndonesiaAustralia Forest Carbon Partnership, Jakarta. [Indonesian]

Ulmer JM, Wolf KL, Backman DR, Tretheway RL, Ja C, Neil-dunne JPMO, Frank LD. 2016. Health \& place multiple health benefits of urban tree canopy: The mounting evidence for a green prescription. Health Place 42: 54-62. DOI: 10.1016/j.healthplace.2016.08.011.

Whitmore TC. 1984. Tropical rain forest of the Par East. Clarendon Press.

Wolsink M. 2016. Environmental education excursions and proximity to urban green space - densification in a 'compact city.' Environ Educ Res 22 (7): 1049-1071. DOI: 10.1080/13504622.2015.1077504.

Yan H, Wu F, Dong L. 2018. Influence of a large urban park on the local urban thermal environment. Sci Total Environ 622: 882-891. DOI: 10.1016/j.scitotenv.2017.11.327.

Yan Y, Zhang C, Hu Y, Kuang W. 2016. Urban land-cover change and its impact on the ecosystem carbon storage in a dryland city. Remote Sens 8 (1): 1-18. DOI: $10.3390 / \mathrm{rs} 8010006$.

Yao L, Chen L, Wei W, Sun R. 2015. Urban forestry \& urban greening potential reduction in urban runoff by green spaces in Beijing: A scenario analysis. Urban For Urban Green 14 (2): 300-308. DOI: 10.1016/j.ufug.2015.02.014.

Zhang Y, Murray AT, Turner BL. 2017. Optimizing green space locations to reduce daytime and nighttime urban heat island effects in Phoenix, Arizona. Landsc. Urban Plan. 165(April): 162-171. DOI: 10.1016/j.landurbplan.2017.04.009.

Zhang B, Xie G, Li N, Wang S. 2015a. Landscape and urban planning effect of urban green space changes on the role of rainwater runoff reduction in Beijing, China. Landsc Urban Plan J 140: 8-16. DOI: 10.1016/j.landurbplan.2015.03.014.

Zhang Y, van Dijk T, Tang J, van den Berg AE. 2015b. Green space attachment and health: A comparative study in two urban neighborhoods. Int J Environ Res Public Health 12 (11): 1434214363. DOI: $10.3390 /$ ijerph121114342.

Zhao J, Ouyang Z, Zheng H, Zhou W, Wang X, Xu W, Ni Y. 2010. Plant species composition in green spaces within the built-up areas of Beijing, China. Plant Ecol 209 (2): 189-204. DOI: 10.1007/s11258009-9675-3.

Zhou X. 2012. Social benefits of urban green space, A conceptual framework of valuation and accessibility measurements. Manag $\begin{array}{lllll}\text { Environ Qual Int J } 23 & \text { (2): 173-189. DOI: }\end{array}$ $10.1108 / 14777831211204921$.

Zölch T, Maderspacher J, Wamsler C, Pauleit S. 2016. Urban forestry \& urban greening using green infrastructure for urban climate-proofing: An evaluation of heat mitigation measures at the micro-scale. Urban For Urban Green 20: 305-316. DOI: 10.1016/j.ufug.2016.09.011 